\title{
Identifying Pollen Donors and Success Rate of Individual Pollinizers in European Plum (Prunus domestica L.) Using Microsatellite Markers
}

\author{
Mekjell Meland ${ }^{1, *}$, Oddmund Frøynes ${ }^{1}$, Milica Fotiric Akšić ${ }^{2}$, Naris Pojskić ${ }^{3}$, \\ Belma Kalamujić Stroil ${ }^{3}$, Lejla Lasic ${ }^{3}$ and Fuad Gasi ${ }^{4}$ \\ 1 Norwegian Institute of Bioeconomy Research-NIBIO Ullensvang, N-5781 Lofthus, Norway; \\ oddmund.froynes@nibio.no \\ 2 Faculty of Agriculture, University of Belgrade, 11000 Belgrade, Serbia; fotiric@agrif.bg.ac.rs \\ 3 Institute for Genetic Engineering and Biotechnology, University of Sarajevo, Laboratory for Molecular \\ Genetics of Natural Resources, Zmaja od Bosne 8, Kampus, 71000 Sarajevo, Bosnia and Herzegovina; \\ naris.pojskic@ingeb.unsa.ba (N.P.); belma.kalamujic@ingeb.ba (B.K.S.); lejla.lasic@ingeb.unsa.ba (L.L.) \\ 4 Faculty of Agriculture and Food Sciences, University of Sarajevo, Zmaja od Bosne 8, 71000 Sarajevo, Bosnia \\ and Herzegovina; f.gasi@ppf.unsa.ba \\ * Correspondence: mekjell.meland@nibio.no
}

Received: 18 January 2020; Accepted: 9 February 2020; Published: 12 February 2020

\begin{abstract}
European plum cultivars (Prunus domestica L.) are hexaploid and partially self-fertile or self-sterile requiring compatible pollinizers with overlapping bloom times. Therefore, inter-planting of different pollinizer cultivars is recommended. In order to identify successful pollinizers of the plum cultivars 'Edda', 'Opal' (self-fertile), 'Jubileum', 'Reeves', 'Mallard', 'Avalon', 'Cacanska Lepotica' (self-fertile), and 'Valor', 60 fruits per cultivar were collected from nine orchards in 2017 and 2018, all of which were located in Ullensvang, western Norway. DNA extraction was subsequently conducted from the obtained embryos, followed by genetic characterization using seven microsatellite markers. Tissue samples from all possible pollinizers were collected during the summer of 2017 and the same DNA approach was conducted. Results showed that 'Opal' was the most successful pollinizer among the investigated plum cultivars. The main exception was 'Cacanska Lepotica', which consistently displayed very high level of self-pollination. The most successful foreign pollinizer of 'Opal' was 'Mallard'. However, in more than two thirds of embryos extracted from 'Opal' fruits self-fertilization was determined. 'Reeves' was identified as the most successful pollinizer among embryos collected from 'Valor'. Among the five cultivars ('Edda', 'Jubileum', 'Reeves', 'Mallard', and 'Avalon') that did not display self-pollination, the pollinizer success rate of 'Opal', ranged from 36.5\% ('Mallard') to 93.5\% ('Edda') in 2017, while in 2018 this rate ranged from 43.5\% ('Jubileum' and 'Reeves') up to $96.5 \%$ ('Edda'). Overall, genotyping embryos using SSRs (simple sequence repeats) proved an effective method in determining the success rate of individual pollinizers among European plum cultivars.
\end{abstract}

Keywords: Prunus domestica L.; paternity analyses; self-fertility; DNA markers

\section{Introduction}

Plum production in Norway is located in the most suitable climatic regions, along fjordside in western Norway and around lakes in Eastern Norway. Due to the Gulf Stream, winter or blossom frost rarely occurs. Only the hexaploid $(2 n=6 x=48)$ European plum (Prunus domestica L.) is cultivated and it relies on the use of high yielding cultivars. These genotypes are well adapted to the production in the Nordic climate, where moderate to low temperatures and precipitation during spring can be a limiting factor for good pollination and fruit set. Fruit set and yield optimization in orchards depend 
on the success of pollination and fertilization [1] which in turn depend on degree of self-fertility [2], certain pollen performance traits [3,4], as well as pollen tube growth and ovule longevity [5]. There is a wide variation in the self-fertility among European plum genotypes and some are completely self-incompatible [6-8]. Partially self-fertile and self-sterile cultivars require compatible pollinizer with overlapping bloom times to produce high, stable yields [9].

Considering that the profitability of fruit growing is strongly affected by fruit set percentage [10], insights into the level of self-fertility as well as cross-pollination among cultivars is of a great value. However, an undesirable effect of self-fertility in plum is over-setting with fruit thinning being necessary to obtain large fruits and avoid alternative bearing [11,12].

A poor fruit set in some plum cultivars may occur due to genetic predisposition resulting in the development of irregular embryo sacs, as well as low temperatures during the blooming period. This may lead to weak growth of the pollen tubes [13]. Apart from these, a poor fruit set may occur as a result of a short effective pollination period (EPP) coined by Williams [14], who defined it as the difference between the duration of vitality of ovules and the time needed for the pollen tubes to reach the ovules. A short interval of stigma receptiveness is certainly a disadvantage, since it may result in a low fruit set.

One of the characteristics of global climatic warming is the increase in the frequency of extreme temperatures, which have an impact on the reduced success rate of fertilization, thereby causing a low fruit set [15]. High temperatures during full bloom have a bigger impact on the female gametophyte, causing a rapid degeneration of the embryo sac and ovule, compared to the impact on the germination of pollen at the stigma and the growth of pollen tubes in the style [16]. Conversely, low temperatures occurring at the time of bloom tend to reduce the pollen tube growth rates in the ovary, thereby shortening the effective pollination period (EPP) [17].

Determination of self-compatibility and crossing combinations between different plum cultivars can successfully be carried out through controlled hybridization [1]. In addition, the observation of pollen tube growth in the style under fluorescent microscope is a fully effective method for the determination of crossing ability in plums [18]. Although the mentioned techniques are very useful, they do not identify the most efficient pollinizer genotype and they do not provide an insight into the actual level of self-pollination in specific field conditions. An alternative approach, to the previously mentioned ones, relies on the molecular data that can be obtained by genotyping embryos extracted from open pollinated fruits of various plum cultivars. Genetic data on the embryos, together with the same data set on mother genotype and pollinizer cultivars can then be used to determine the most likely parentage of the analyzed embryos. Further analyses enable the assessment of pollinizer efficacy among a set of individual pollen donors. An insight into the level of self-pollination of the self-fertile plum cultivars, as well as the assessment of individual pollinizer efficacy, in field conditions, can serve as a valuable guideline to plum producers.

Microsatellites or SSRs (simple sequence repeats) have previously been used for diversity studies of plum germplasm in France [19], Germany [20], Croatia [21], Sweden [22], Greece [23], Hungary [24], Spain [25], and Romania [26]. This marker system can also efficiently be used for parentage analyses in plum. This approach was already employed in parent-offspring analyses on plum [27] that used microsatellite data in order to clarify parentage of three Cacak cultivars. SSR marker systems can also be used for identifying the male parent (successful pollinizer) in open pollinated fruit in commercial orchards. A recent example is the use of microsatellite markers for identifying pollinizer efficacy, through parentage analyses of pear seeds, on the pear cultivar 'Ingeborg' in Norway [28]. A similar approach was employed by Nishio [29] in order to estimate the effective pollen dispersal distance for cross-pollination in chestnut orchards. Another use of a molecular approach has been applied in determination of the pollen-mediate gene flow from GMO (genetically modified organism) plum cultivar 'Honeysweet' to other plum cultivars [30]. However, this approach relied on the use of a GUS reporter system (GUS: $\beta$-glucuronidase), which is only applicable on 'Honeysweet', due to its genetically engineered nature. 
In this study, embryos of eight European plum cultivars: 'Edda' ('Czar' $\times$ 'Pêche'), 'Opal' ('Oullins Gage' $\times$ 'Early Favourite'), 'Jubileum' ('Giant' $\times$ 'Yakima'), 'Reeves' (Canadian plum seedling), 'Mallard' (old English plum seedling), 'Avalon' ('Reeves' open pollinated), 'Cacanska Lepotica' ('Wangeheims Frühzwetsche' $\times$ 'Požegača') ), and 'Valor' ('Imperial Epineuse' $\times$ 'Grand Duke') were extracted for two consecutive years and analyzed using SSR markers. The aim of this study was to identify the pollen donor for each embryo and to determine the success rate of individual plum pollinizers within orchards located in Ullensvang, Norway's largest fruit producing region.

\section{Materials and Methods}

\subsection{Plant Material and Experimental Design}

During the autumns of 2017 and 2018, 10 random, fully mature, and fully developed plums, for each examined cultivar, were collected from the beginning, middle, and end of the planting rows, totaling in 30 fruits per cultivar each year. The sampling was conducted entirely randomly, throughout the examined orchards, irrespective of the proximity of pollinizer rows. Fruits were harvested from the following plum cultivars: 'Edda', 'Opal' (self-fertile), 'Jubileum', 'Reeves', 'Mallard', 'Avalon', 'Cacanska Lepotica' (self-fertile), and 'Valor' grown in nine different orchards located in Ullensvang, western Norway (Table 1). Each cultivar was investigated in two different orchards for every season. The same orchards were sampled in 2017 and 2018 except for two cultivars: 'Jubileum' and 'Avalon'. The reason for this change was that those trees were grabbed after the first season and replacement orchards had to be found. Productive, mature, and uniform slender spindle trees, spaced at 1.5-2 $\times 4$ $\mathrm{m}$ and pruned to a maximum height of $2.5 \mathrm{~m}$, were used. Trees were irrigated by drip irrigation when water deficits occurred. The pollinizers were planted in single rows, and with very few exceptions, each pollinizer (consisting mostly of commercial plum cultivars) constituted a minimum of $10 \%$ of all plum trees present in the examined orchards (Table 2).

Tissue samples (young leaves) were collected in the summer of 2017, from all the main genotypes and pollinizers at the NIBIO Ullensvang (Norwegian Institute of Bioeconomy Research) experimental plum orchard and all other examined orchards. Twenty young leaves from each plum genotype were picked and placed in paper envelopes, together with a tablespoon of silica gel. The following 11 cultivars were sampled: 'Herman', 'Edda', 'Mallard', 'Victoria', 'Opal', 'Avalon', 'Valor', 'Cacanska Lepotica', 'Jubileum', 'Excalibur', and 'Reeves'.

The abundance of each main cultivar and pollinizer within the orchards and adjacent sites (200 $\mathrm{m}$ radius from sampled trees), as well as the flowering overlap between the pollinizers and the cultivars that provided the plum kernels are presented in Table 2.

Weather data before, during and after the plum flowering in 2017 and 2018 was collected from meteorological stations located in Ullensvang (available at: https://mt.nibio.no/agrometbase/ getweatherdata_new.php) and are presented in Figures 1 and 2. 
Table 1. Nine orchards, located in Ullensvang Norway, used to collect 480 fully open pollinated mature fruits from following plum cultivars: 'Edda', 'Opal', 'Jubileum', 'Reeves', 'Mallard', 'Avalon', 'Cacanska Lepotica', and 'Valor'. Specific orchards sampled for each individual plum cultivar, for each of the investigated seasons, are marked in the table.

\begin{tabular}{|c|c|c|c|c|c|c|c|c|c|c|c|c|c|c|c|c|}
\hline \multirow{2}{*}{$\begin{array}{c}\text { Cultivars } \\
\text { Orchards/year }\end{array}$} & \multicolumn{2}{|c|}{ 'Edda' } & \multicolumn{2}{|c|}{ ‘Opal' } & \multicolumn{2}{|c|}{ 'Jubileum' } & \multicolumn{2}{|c|}{ 'Reeves' } & \multicolumn{2}{|c|}{ 'Mallard' } & \multicolumn{2}{|c|}{ 'Avalon' } & \multicolumn{2}{|c|}{ ‘Cacanska Lepotica' } & \multicolumn{2}{|c|}{ ‘Valor' } \\
\hline & $' 17$ & $' 18$ & ‘17 & ‘18 & $` 17$ & $` 18$ & $‘ 17$ & ‘18 & $' 17$ & $‘ 18$ & $' 17$ & $' 18$ & $‘ 17$ & $` 18$ & $' 17$ & $' 18$ \\
\hline Orchard 1 & $x$ & $x$ & & & & & & & & & & & & & & \\
\hline Orchard 2 & & & & & & $x$ & & & & & & & & & & \\
\hline Orchard 3 & $x$ & $x$ & & & & & & & & & & & & & & \\
\hline Orchard 4 & & & $x$ & $x$ & & & $x$ & $\mathrm{x}$ & $\mathrm{x}$ & $\mathrm{x}$ & $\mathrm{x}$ & & & & & \\
\hline Orchard 5 & & & $x$ & $x$ & $x$ & $\mathrm{x}$ & $x$ & $x$ & $x$ & $\mathrm{x}$ & $\mathrm{x}$ & $x$ & $\mathrm{x}$ & $\mathrm{x}$ & $x$ & $x$ \\
\hline Orchard 6 & & & & & $\mathrm{x}$ & & & & & & & & & & & \\
\hline Orchard 7 & & & & & & & & & & & & $x$ & & & & \\
\hline Orchard 8 & & & & & & & & & & & & & & & $x$ & $\mathrm{x}$ \\
\hline Orchard 9 & & & & & & & & & & & & & $x$ & $x$ & & \\
\hline
\end{tabular}


Table 2. The abundance of each main cultivar and pollinizer within the orchards sampled in this study, as well as within the adjacent sites (200 $\mathrm{m}$ radius from sampled trees), expressed in percentage of the overall number of trees.

\begin{tabular}{|c|c|c|c|c|c|c|c|c|c|c|}
\hline Pollinizer & Year & Orchard 1 & Orchard 2 & Orchard 3 & Orchard 4 & Orchard 5 & Orchard 6 & Orchard 7 & Orchard 8 & Orchard 9 \\
\hline \multirow{2}{*}{ 'Edda' } & '17 & 10 & & 50 & & & & & & \\
\hline & $‘ 18$ & 10 & 20 & 50 & & & & & & \\
\hline \multirow{2}{*}{ ‘Opal' } & ‘ 17 & 70 & & 50 & 10 & 20 & 10 & & 30 & \\
\hline & $‘ 18$ & 70 & 50 & 50 & 10 & 20 & & 10 & 30 & \\
\hline \multirow{2}{*}{ ‘Jubileum' } & $‘ 17$ & 15 & & & & 9 & 5 & & & \\
\hline & ‘18 & 20 & 20 & & & 9 & & & & \\
\hline \multirow{2}{*}{ 'Reeves' } & $‘ 17$ & & & & 30 & 20 & & & 30 & \\
\hline & $' 18$ & & & & 50 & 20 & & 20 & 30 & \\
\hline \multirow{2}{*}{ 'Mallard' } & $‘ 17$ & & & & 25 & 21 & & & 30 & \\
\hline & $' 18$ & & & & 38 & 21 & & 20 & 30 & \\
\hline \multirow{2}{*}{ Avalon } & ‘17 & & & & 34 & 9 & 5 & & & \\
\hline & $‘ 18$ & & & & & 9 & & 40 & & \\
\hline \multirow{2}{*}{ ‘Valor’ } & ‘17 & & & & & 10 & 30 & & 5 & \\
\hline & ‘18 & & & & & 10 & & & 5 & \\
\hline ‘Cacanska & $‘ 17$ & & & & 1 & 11 & & & & 50 \\
\hline Lepotica' & $‘ 18$ & & & & 2 & 11 & & & & 50 \\
\hline \multirow{2}{*}{ 'Herman' } & $‘ 17$ & 5 & & & & & & & & \\
\hline & $' 18$ & & & & & & & & & \\
\hline \multirow{2}{*}{ 'Victoria' } & ‘17 & & & & & & & & 5 & 50 \\
\hline & $' 18$ & & 10 & & & & & & 5 & 50 \\
\hline \multirow{2}{*}{ 'Excalibur' } & $‘ 17$ & & & & & & 50 & & & \\
\hline & ‘ 18 & & & & & & & 10 & & \\
\hline
\end{tabular}




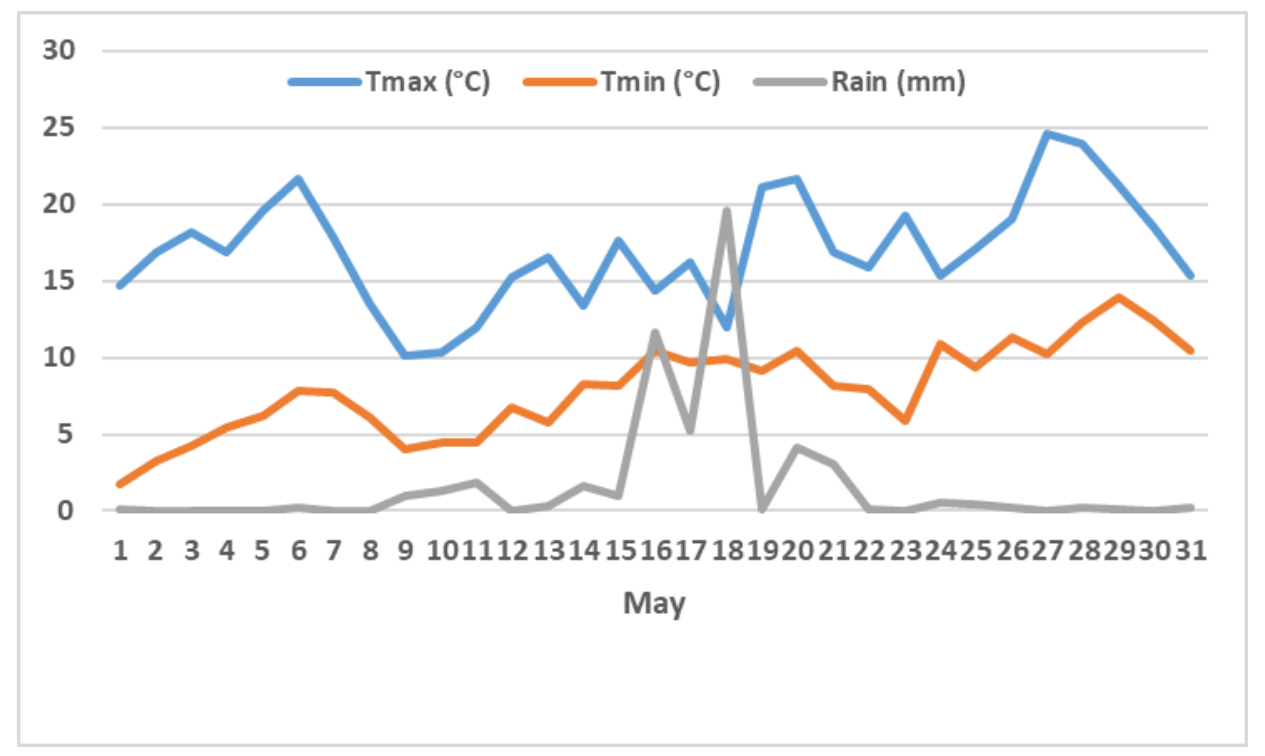

Figure 1. Minimum (Tmin), maximum (Tmax), and rain fall in May 2017 at NIBIO Ullensvang (Norwegian Institute of Bioeconomy Research), Norway.

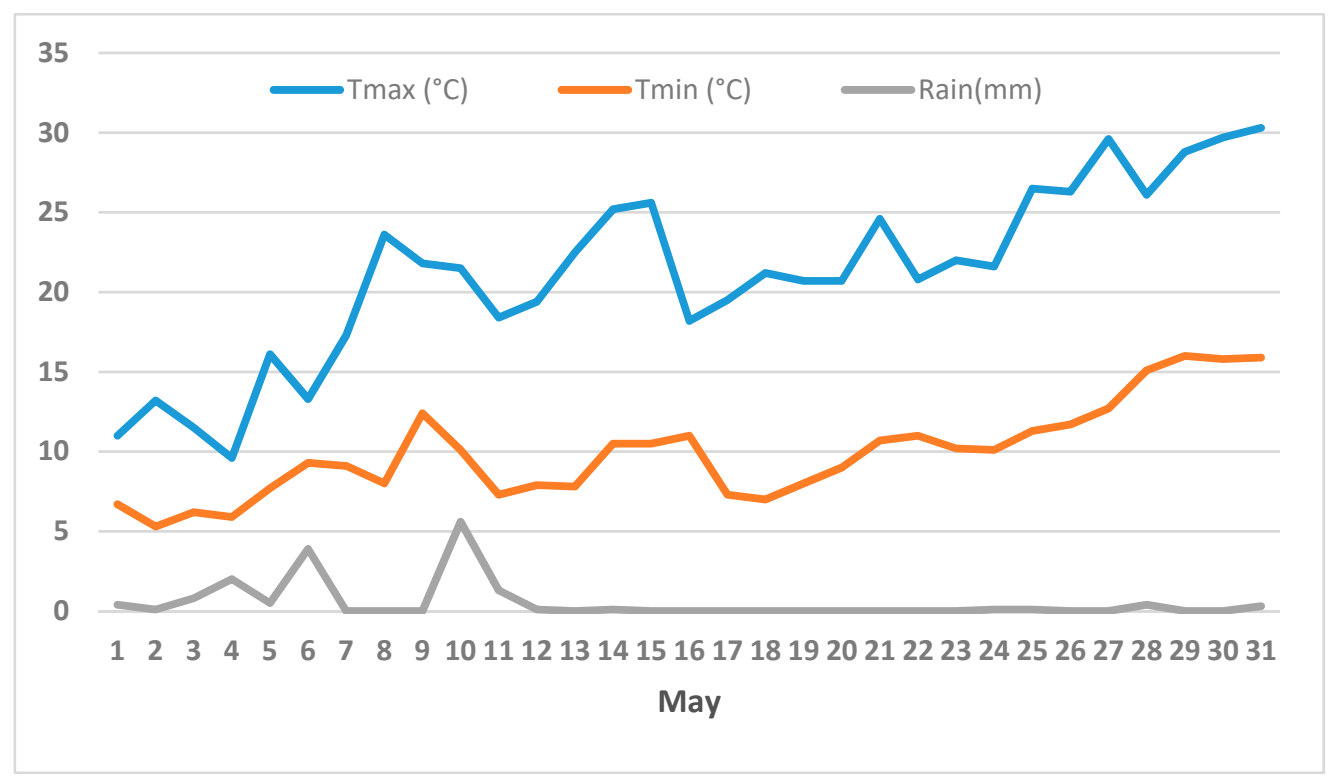

Figure 2. Minimum (Tmin), maximum (Tmax), and rain fall in May 2018 at NIBIO Ullensvang, (Norwegian Institute of Bioeconomy Research), Norway.

\subsection{SSR Genotyping}

After harvest, kernels were separated from the fruits, broken open, and embryos were extracted for genetic analyses. Genomic DNA from embryos and leaves was isolated using Qiagen Dneasy ${ }^{\mathrm{TM}}$ Plant Mini Kit (Qiagen AB, Sollentuna, Sweden), following the manufacturer's instructions. Genetic characterization was conducted using seven microsatellite markers, selected from two previous molecular studies on plum and following the parameters used in those studies [21,22]. The selection was based on their polymorphism and scoring simplicity. The following microsatellite markers were chosen: ВPPCT034, ВРPCT039, ВРPCT040, ВPPCT014 [31], PacA33 [32], UDP96, UDP98 [33]. Additional three microsatellite markers were used in all cases where there was any ambiguity regarding the paternity (after the genotyping of collected plum kernels). 
The number of different alleles and gene diversity [34] was calculated using SPAGeDI 1.3 [35]. Microsatellite data, obtained for the analyzed cultivars and embryos, was used for paternity analyses. Although there are numerous available software solutions for paternity testing of diploid and even autopolyploid species, we found no adequate program for identifying male parents among allopolyploid samples, based on SSR data. Presumably the main obstacle in developing such a program is the inability to identify the allele copy number for each detected microsatellite allele. Therefore, in this study the obtained SSR data for the sampled cultivars (mother genotypes), pollinizers, and each analyzed embryo was searched in order to determine the most likely male parent for each individual progeny, a slight modification of Decroocq et al. [27]. The main criteria were the presence of obligatory alleles (alleles registered in the embryos, but not present in the mother genotype) among individual pollinizers. Additional criteria required that potentially half of the alleles registered within each progeny could be assigned to the male parent. In order to confirm these findings, we calculated maximum likelihood within Genodive $2.0 \mathrm{~b} 23$ software [36] using the assignment approach. This method, suitable for allopolyploids, allowed for the confirmation of the most likely male parent for embryos collected from each sampled plum cultivar.

In order to evaluate the relationship between the tree abundance, within the orchards, of individual pollinizers and their success of pollinations, a Chi-square test (sampled vs. expected) was applied within PAST v.3.26 program [37].

Due to the relatively small number of observations, we applied the Monte Carlo permutation test using 9999 random replicates. In this way, we estimated the effect of sample size on the statistical significance of results. The considered level of statistical significance was $p<0.05$.

\section{Results and Discussion}

\subsection{SSR Polymorphism}

Seven primer pairs amplified 84 distinct alleles among the 11 genotypes, consisting of eight main cultivars and their potential pollinizers, or on average 12 alleles per locus (Table 3). The detected number of alleles ranged from eight for locus BPPCT 40 to 14 for locus BPPCT 34. A relatively high number of alleles, detected among a small set of genotypes, is a consequence of the hexaploid nature of plum as well as the fact that the analyzed cultivars have a very diverse pedigree. High values for the mean number of alleles per locus in plum is reported by numerous studies [19-26]. In the mentioned studies, this value ranged from 18.7 to 29 alleles. However, all the cited studies were conducted on germplasm collections, containing a much higher number of diverse plum accessions.

Gene diversity among main cultivars and pollinizers, as calculated according to Nei [34], ranged from 0.85 for UDP96 to 0.91 for BPPCT 40, and had an overall rather high average of 0.89 . The calculated value for this parameter was very similar to values reported by earlier plum germplasm studies.

Among the embryos genotyped in 2017, the detected number of alleles ranged from 35, for kernels collected from 'Cacanska Lepotica', to 63, for kernels collected from 'Valor' (Table 3). Gene diversity, calculated for the embryos of the various plum cultivars in 2017, was lowest for 'Cacanska Lepotica' kernels (0.74) and highest for 'Valor' (0.83). The results were somewhat different in 2018, where kernels collected from 'Edda' and 'Cacanska Lepotica' displayed the lowest number of different alleles (48 and 51 alleles, respectively), while genotyped embryos collected from 'Jubileum' and 'Reeves' fruits possessed the highest number of distinct alleles (64). The lowest value for gene diversity was again detected among the kernels sampled from 'Cacanska Lepotica' (0.75). These findings correlate very well to the levels of self-pollination, detected using the microsatellite markers, which was on average 93\% for 'Cacanska Lepotica' in 2017 and 77\% in 2018 (Table 4). High levels of self-compatibility have been previously determined for 'Cacanska Lepotica' by Ogašanović [38], as well as by Nikolić and Milatović [2]. Other self-pollination was noticed in 'Opal' (73.0\% and 50.0\% in 2017 and 2018, respectively), as well as negligibly for 'Valor' (4\% in 2017). 
Table 3. Number of alleles per locus (Na) and gene diversity (He) [34] for the main and pollinizer cultivars ('Herman', 'Edda', 'Mallard', 'Victoria', 'Opal', 'Avalon', 'Valor', 'Cacanska Lepotica', 'Jubileum', 'Excalibur', and 'Reeves'), as well for, collected 'Edda', 'Opal', 'Jubileum', 'Reeves', 'Mallard', 'Avalon', 'Cacanska Lepotica', and 'Valor' embryos, in 2017 and 2018, based on seven SSR (simple sequence repeat) loci.

\begin{tabular}{|c|c|c|c|c|c|c|c|c|c|c|c|c|c|c|c|c|c|}
\hline & \multirow{2}{*}{$\begin{array}{c}\text { Main cv. } \\
\text { and poll. }\end{array}$} & \multicolumn{2}{|c|}{ 'Edda' kernels } & \multicolumn{2}{|c|}{ ‘Opal' kernels } & \multicolumn{2}{|c|}{$\begin{array}{l}\text { 'Jubileum' } \\
\text { kernels }\end{array}$} & \multicolumn{2}{|c|}{$\begin{array}{l}\text { 'Reeves' } \\
\text { kernels }\end{array}$} & \multicolumn{2}{|c|}{$\begin{array}{l}\text { 'Mallard' } \\
\text { kernels }\end{array}$} & \multicolumn{2}{|c|}{$\begin{array}{l}\text { 'Avalon' } \\
\text { kernels }\end{array}$} & \multicolumn{2}{|c|}{$\begin{array}{c}\text { 'Cacanska } \\
\text { Lepotica' } \\
\text { kernels }\end{array}$} & \multicolumn{2}{|c|}{ ‘Valor' kernels } \\
\hline & & $\mathrm{Na}{ }^{\prime} 17$ & $\mathrm{Na}{ }^{\prime} 18$ & $\mathrm{Na}{ }^{\prime} 17$ & $\mathrm{Na}{ }^{\prime} 18$ & $\mathrm{Na}{ }^{\prime} 17$ & $\mathrm{Na}{ }^{\prime} 18$ & $\mathrm{Na}{ }^{\prime} 17$ & $\mathrm{Na}{ }^{\prime} 18$ & $\mathrm{Na}{ }^{\prime} 17$ & $\mathrm{Na}{ }^{\prime} 18$ & $\mathrm{Na}{ }^{\prime} 17$ & $\mathrm{Na} ` 18$ & $\mathrm{Na}{ }^{\prime} 17$ & $\mathrm{Na}{ }^{\prime} 18$ & $\mathrm{Na}{ }^{\prime} 17$ & $\mathrm{Na} ' 18$ \\
\hline ВРРСТ034 & 14 & 8 & 8 & 9 & 10 & 9 & 10 & 9 & 9 & 11 & 11 & 11 & 11 & 7 & 10 & 13 & 9 \\
\hline ВРРСТ039 & 13 & 9 & 8 & 8 & 6 & 9 & 8 & 7 & 10 & 10 & 8 & 8 & 8 & 4 & 6 & 9 & 8 \\
\hline ВРРСТ 040 & 8 & 7 & 6 & 7 & 8 & 8 & 7 & 7 & 8 & 8 & 8 & 8 & 8 & 5 & 7 & 8 & 8 \\
\hline PacA33 & 13 & 6 & 5 & 5 & 8 & 6 & 8 & 8 & 8 & 5 & 8 & 7 & 8 & 4 & 7 & 9 & 9 \\
\hline ВРРСТ014 & 13 & 8 & 6 & 8 & 10 & 9 & 11 & 11 & 12 & 12 & 10 & 9 & 10 & 7 & 7 & 10 & 9 \\
\hline UDP96 & 11 & 7 & 8 & 8 & 9 & 8 & 10 & 9 & 10 & 9 & 9 & 9 & 8 & 3 & 8 & 7 & 5 \\
\hline UDP98 & 12 & 8 & 7 & 5 & 9 & 7 & 10 & 8 & 7 & 6 & 8 & 8 & 8 & 5 & 6 & 7 & 6 \\
\hline \multirow[t]{2}{*}{ Mean } & 12.00 & 7.57 & 6.86 & 7.14 & 8.57 & 8.00 & 9.14 & 8.43 & 9.14 & 8.71 & 8.86 & 8.57 & 8.71 & 5.00 & 7.29 & 9.00 & 7.71 \\
\hline & $\mathrm{He}$ & $\mathrm{He}^{\prime} 17$ & $\mathrm{He}^{\prime} 18$ & $\mathrm{He}^{\prime} 17$ & $\mathrm{He}^{\prime} 18$ & $\mathrm{He}^{\prime} 17$ & $\mathrm{He}^{\prime} 18$ & $\mathrm{He}^{\prime} 17$ & $\mathrm{He}^{\prime} 18$ & $\mathrm{He}^{\prime} 17$ & $\mathrm{He}^{\prime} 18$ & $\mathrm{He}^{\prime} 17$ & $\mathrm{He}^{\prime} 18$ & $\mathrm{He}^{\prime} 17$ & $\mathrm{He}^{\prime} 18$ & $\mathrm{He}^{\prime} 17$ & $\mathrm{He}^{\prime} 18$ \\
\hline ВРРСТ034 & 0.91 & 0.85 & 0.85 & 0.71 & 0.76 & 0.81 & 0.83 & 0.83 & 0.82 & 0.86 & 0.84 & 0.82 & 0.84 & 0.84 & 0.83 & 0.88 & 0.85 \\
\hline ВРРСТ039 & 0.90 & 0.87 & 0.87 & 0.84 & 0.82 & 0.85 & 0.81 & 0.80 & 0.83 & 0.82 & 0.83 & 0.80 & 0.82 & 0.75 & 0.76 & 0.85 & 0.85 \\
\hline ВРРСТ040 & 0.88 & 0.82 & 0.82 & 0.77 & 0.81 & 0.83 & 0.83 & 0.85 & 0.87 & 0.87 & 0.87 & 0.86 & 0.86 & 0.80 & 0.82 & 0.85 & 0.87 \\
\hline PacA33 & 0.88 & 0.74 & 0.72 & 0.68 & 0.73 & 0.76 & 0.82 & 0.79 & 0.81 & 0.78 & 0.82 & 0.75 & 0.82 & 0.68 & 0.70 & 0.84 & 0.86 \\
\hline ВРРСТ014 & 0.90 & 0.83 & 0.80 & 0.81 & 0.83 & 0.86 & 0.85 & 0.88 & 0.88 & 0.85 & 0.85 & 0.86 & 0.86 & 0.69 & 0.72 & 0.87 & 0.87 \\
\hline UDP96 & 0.85 & 0.83 & 0.84 & 0.78 & 0.84 & 0.86 & 0.83 & 0.84 & 0.83 & 0.78 & 0.84 & 0.83 & 0.83 & 0.63 & 0.69 & 0.70 & 0.61 \\
\hline UDP98 & 0.89 & 0.82 & 0.82 & 0.56 & 0.64 & 0.81 & 0.76 & 0.70 & 0.71 & 0.74 & 0.78 & 0.74 & 0.77 & 0.74 & 0.72 & 0.79 & 0.73 \\
\hline Mean & 0.89 & 0.82 & 0.82 & 0.74 & 0.78 & 0.83 & 0.82 & 0.81 & 0.82 & 0.81 & 0.83 & 0.81 & 0.83 & 0.73 & 0.75 & 0.83 & 0.81 \\
\hline
\end{tabular}


Table 4. Success rate of 11 pollinizers (expressed in percentage) among eight plum cultivars, calculated during two seasons in nine orchards, located in Ullensvang, Norway. The data for calculation was obtained through genotyping of 480 plum embryos, using seven SSR markers, and consequent positive identification of pollen donors.

\begin{tabular}{|c|c|c|c|c|c|c|c|c|c|}
\hline Pollinizers & Cultivar & 'Edda' & 'Opal' & 'Jubileum' & 'Reeves' & 'Mallard' & 'Avalon' & 'Cacanska Lepotica' & 'Valor' \\
\hline & Season & & & & & & & & \\
\hline \multirow{2}{*}{ 'Edda' } & $‘ 17$ & & & & & & & & \\
\hline & $' 18$ & & & & & & & & \\
\hline \multirow{2}{*}{ 'Opal' } & $‘ 17$ & 93.5 & 73 & 73 & 83.5 & 36.5 & 50 & & 20 \\
\hline & $' 18$ & 96.5 & 50 & 43.5 & 43 & 53.5 & 60 & & 26.5 \\
\hline \multirow{2}{*}{ 'Jubileum' } & '17 & 6.5 & 3.5 & & 6.5 & 20 & 23.5 & & \\
\hline & $' 18$ & & 16.5 & & 33.5 & 30 & 13.5 & & \\
\hline \multirow{2}{*}{ 'Reeves' } & $' 17$ & & 3.5 & & & 13.5 & 3 & 3.5 & 71.5 \\
\hline & $‘ 18$ & & 23 & 13.5 & & 10 & & 3.5 & 73.5 \\
\hline \multirow{2}{*}{ 'Mallard' } & $' 17$ & & 16.5 & & 6.5 & & & & \\
\hline & $' 18$ & & 3.5 & 6.5 & 20 & & 23 & & \\
\hline \multirow{2}{*}{ 'Avalon' } & '17 & & & 13.5 & & & & & \\
\hline & $' 18$ & & 3.5 & & & & & 3.5 & \\
\hline \multirow{2}{*}{ 'Valor' } & '17 & & & 10 & & & & & 2 \\
\hline & $' 18$ & & 3.5 & & & & 3.5 & & \\
\hline Lepotica' & $' 18$ & 3.5 & & & & 6.5 & & 76.5 & \\
\hline \multirow{2}{*}{ 'Herman' } & '17 & & & & & & & & \\
\hline & $' 18$ & & & & & & & & \\
\hline \multirow{2}{*}{ 'Victoria' } & '17 & & & & 3.5 & & & 3.5 & \\
\hline & $' 18$ & & & 36.5 & & & & 16.5 & \\
\hline \multirow{2}{*}{ 'Excalibur' } & '17 & & & 3.5 & & & & & \\
\hline & $' 18$ & & & & 3.5 & & & & \\
\hline
\end{tabular}


Regarding cultivar 'Edda' (self-incompatible), the low number of alleles detected for its embryos in 2018 can be explained by the fact that during the 2018 growing season, among $95 \%$ of the genotyped 'Edda' kernels, 'Opal' was identified as the successful pollinizer. On the other hand, high values for the number of different alleles and gene diversity, among 'Valor' embryos in 2017, as well as 'Jubileum' and 'Reeves' embryos in 2018 is due to pollen contribution from a more diverse set of donors (Table 4).

Much higher levels of cross-pollination, among 'Cacanska Lepotica' and 'Opal', in 2018 compared to 2017 are in line with the values for the average alleles per locus, obtained on all plum embryos collected in 2017 and 2018, respectively. Namely, average number of alleles per locus, calculated for all plum embryos in 2017 was 6.9, while in 2018 it was 7.4. Higher values obtained for 2018 indicate that a more diverse set of donors contributed with pollen in this growing season and that the pollen contribution was more evenly distributed among various pollinizers. A comparable conclusion has previously been drawn in a similar study on pear cultivar 'Ingeborg' in Norway [28], where higher allele diversity among genotyped seeds was also correlated to pollen contribution by a more diverse set of donors. These changes in pollination patterns between seasons can usually be ascribed to variations in environmental factors, such as rainfall and temperature, which may also negatively affect pollinators [17]. Another factor influencing pollination patterns is the variation in overlapping of flowering periods among main cultivars and pollinizers. However, although flowering dates often vary depending on season, the order of cultivars' flowering in most cases remains the same.

\subsection{Climate and Flowering}

In order to explain the decrease of self-pollination from 2017 to 2018, as well as the general increase in cross-pollination diversity, average daily temperatures and the precipitation during the flowering period of the analyzed cultivars was studied. The obtained data indicates that the average pre-flowering temperatures in April were higher in $2018\left(6.5^{\circ} \mathrm{C}\right)$ compared to $2017\left(5.9^{\circ} \mathrm{C}\right)$, while temperature in May $2018\left(15^{\circ} \mathrm{C}\right)$ was $4{ }^{\circ} \mathrm{C}$ higher compared to the same period in $2017\left(11^{\circ} \mathrm{C}\right)$. (Figures 1 and 2). The precipitation was $52.6 \mathrm{~mm}$ in May 2017 compared to $15.0 \mathrm{~mm}$ for the same period in 2018. Higher temperatures had a positive effect on faster pollen tube growth, presumably increasing the probability of successful fertilization from a wider range of pollen donors. Since the most efficient distance for foraging and pollination of Apis mellifera, Bombus sp., and even Osmia sp., is $\approx 1 \mathrm{~km}$ (but can be up to $5 \mathrm{~km}$ ) away from their apiary of origin, and its foraging activity correlates with increased temperature during spring [39-42], we assume that more insects visited plum flowers and brought pollen from a more diverse set of plum pollinizers. It is important to note that in case of mixed pollen loads on stigma, even if cultivar is self-compatible, plant will prevent self-fertilization and favor cross pollination in order to avoid inbreeding depression in the progeny generation [43].

The flowering season started May $9^{\text {th }}$ for the earliest cultivar 'Mallard' and 'Avalon' in 2017 (first bloom) and for the latest flowering cultivar 'Valor' eight days later. In 2017 the flowering periods lasted on average six days from first flower to petal fall for most cultivars, with notable exception for 'Valor' and 'Avalon' (9 and 10 days, respectively). A similar blooming pattern occurred the year after, in which 'Mallard' started to flower on May $8^{\text {th }}$ and 'Valor' on May $13^{\text {th }}$ (Table 5). The order of first bloom and its duration followed a similar pattern among analyzed cultivars in these two seasons. Higher temperatures and less rainfall were beneficial for pollinator activity thus favoring cross-pollination among a larger set of plum cultivars. 
Table 5. Dates of first bloom (10\% of flowers open), full bloom ( $80 \%$ of flowers open), and petal fall in May for 10 investigated plum cultivars and their pollinizer cultivars in Ullensvang, Norway during 2017 and 2018 seasons.

\begin{tabular}{|c|c|c|c|c|c|c|c|c|c|c|c|}
\hline Year & Flowering & 'Edda' & 'Opal' & 'Jubileum' & 'Reeves' & 'Mallard' & 'Avalon' & $\begin{array}{l}\text { 'Cacanska } \\
\text { Lepotica' }\end{array}$ & 'Valor' & 'Victoria' & 'Excalibur' \\
\hline \multirow[t]{3}{*}{2017} & First Bloom & $5 / 11$ & $5 / 12$ & $5 / 13$ & $5 / 14$ & $5 / 9$ & $5 / 9$ & $5 / 13$ & $5 / 17$ & $5 / 12$ & $5 / 14$ \\
\hline & Full Bloom & $5 / 13$ & $5 / 14$ & $5 / 15$ & $5 / 16$ & $5 / 11$ & $5 / 11$ & $5 / 15$ & $5 / 22$ & $5 / 15$ & $5 / 16$ \\
\hline & Petal fall & $5 / 17$ & $5 / 18$ & $5 / 19$ & $5 / 19$ & $5 / 17$ & $5 / 19$ & $5 / 19$ & $5 / 26$ & $5 / 19$ & $5 / 21$ \\
\hline \multirow[t]{3}{*}{2018} & First Bloom & $5 / 9$ & $5 / 9$ & $5 / 9$ & $5 / 12$ & $5 / 8$ & $5 / 9$ & $5 / 12$ & $5 / 13$ & $5 / 9$ & $5 / 10$ \\
\hline & Full Bloom & $5 / 10$ & $5 / 11$ & $5 / 10$ & $5 / 14$ & $5 / 10$ & $5 / 10$ & $5 / 14$ & $5 / 15$ & $5 / 10$ & $5 / 12$ \\
\hline & Petal fall & $5 / 16$ & $5 / 16$ & $5 / 16$ & $5 / 20$ & $5 / 16$ & $5 / 16$ & $5 / 23$ & $5 / 23$ & $5 / 16$ & $5 / 19$ \\
\hline
\end{tabular}


Plum pollination patterns are of a particular significance for the plum producers, especially in light of global climate change. However, besides having a positive effect on cross-pollination, phenological observations in previous studies $[15,44,45]$ proved that higher post-chilling and pre-bloom temperatures can have a negative effect on flower quality, and success rate of fertilization in fruit trees, and thus reduce yields.

\subsection{Identifying Most Successful Pollinizers}

Overall, due to the hexaploid nature of plum, seven primer pairs used in this study managed to amplify enough different alleles needed to identify pollen donors for each embryo. Although the success rate of individual plum pollinizers varied somewhat among the various analyzed orchards, as well as between the 2017 and 2018 growing season, it is possible to conclude that 'Opal' was the most successful pollinizer among the investigated plum cultivars. The only exceptions were 'Cacanska Lepotica', which consistently displayed very high level of self-pollination and the plum cultivar 'Valor'. Although, 'Opal' was identified as the pollen donor in 20\% of kernels collected from 'Valor' in 2017 and $26.5 \%$ in 2018 , 'Reeves' was identified as the most successful pollinizer among embryos collected from 'Valor' (above 70\% in both seasons). Lower success rate of 'Opal', as well as high success rate of 'Reeves', is probably mainly due to the big difference in flowering period between 'Opal' and 'Valor' but overlapping between 'Reeves' and Valor'. The difference in full bloom between 'Opal' and 'Valor' was eight days in 2017 and four days in 2018 (Table 5). On the other hand, the difference in full bloom between 'Reeves' and 'Valor' was six days in 2017 (the shortest between 'Valor' and any other analyzed cultivars in that season) and one day in 2018. According to Kemp and Wertheim [46] (as cited by Koskela [1]) overlapping is considered too short if the difference between the dates of full bloom is six days or more. The ability of 'Reeves' to efficiently fertilize 'Valor' during 2017 season, in spite of a six day difference between the dates of full bloom, is probably due to an overall prolonged plum flowering period, caused by lower temperatures in 2017, or possibly longer life span of Valor's egg cells. Aside from 'Valor', the difference between the dates of full bloom among all other plum cultivar was less than six days, in both investigated seasons (Table 5). It is therefore reasonable to assume that flowering overlap period was not a significant cause of the success 'Opal' had as a pollen donor, compared to other pollinizers in this study. Among the five cultivars ('Edda', 'Jubileum', 'Reeves', 'Mallard', and 'Avalon') that did not display self-pollination, the success rate of 'Opal', in 2017, ranged from 36.5\% for 'Mallard' to 93.5\% for 'Edda'. In 2018, 'Opal' had the lowest success rate among 'Jubileum' and 'Reeves' (43.5\%) and highest again among 'Edda' plum trees (96.5\%). Keulemans [47] has reported fast tube growth of 'Opal' pollen, even under low temperature conditions, which is probably a significant contributor to the overall success of this plum cultivar as a pollinizer.

In order to examine if the abundance of pollinizers within the investigated orchards was linked to their particular success ratio as a pollen donor, a chi-squared test was conducted on all plum cultivars, except for the ones that displayed very high levels of self-fertilization ('Opal' and 'Cacanska Lepotica'). The results of the test revealed that there was a significant difference $(p<0.05)$ between the abundance of pollinizer within the orchards and their success in fertilizing any of the remaining six plum cultivars ('Edda', 'Jubileum', 'Reeves', 'Mallard', 'Avalon', and 'Valor'). Although the most successful pollinizer in our study ('Opal') is widely present in most of the examined orchards, it was not the most abundant cultivar. Apparently, additional factors, such as proximity of the pollinizer tree to the sampled cultivar tree, large number of flowers secreting nectar that attract insects, as well as the ability of certain plum cultivars to produce large amounts of fast-growing pollen grains represents an important factor in overall success of a pollinizer.

\section{Conclusions}

The cultivar 'Opal' was the most successful pollinizer for all the investigated plum cultivars and should be planted as the main pollinizer in Norwegian plum orchards. 'Cacanska Lepotica' and 'Opal' are partially self-pollinated cultivars that consistently display high level of auto-fertilization. The most 
successful foreign pollinizer of 'Opal' was 'Mallard', as was 'Victoria' for 'Cacanska Lepotica', while 'Reeves' was identified as the most successful pollinizer for 'Valor'.

SSR genotyping of embryos represents a very efficient method in the identification of pollinizer efficacy and can be applied to other fruit species and cultivars for determining the best combination of cultivars within the orchard in order to improve fruit set.

Author Contributions: Conceptualization, F.G. and M.M.; methodology and formal analysis, N.P., B.K.S., L.L. and O.F.; writing — original draft preparation F.G. writing - review and editing M.F.A., M.M. and F.G.; project administration M.M., and funding acquisition; M.M. All authors have read and agreed to the published version of the manuscript.

Funding: This study was supported by The Research Council of Norway (project No. 269227).

Acknowledgments: The authors would like to thank Marianne Hotle and Mari Vedå Bredal, Norwegian Institute of Bioeconomy Research for technical support during experimentation.

Conflicts of Interest: The authors declare no conflict of interest.

\section{References}

1. Koskela, E.; Kemp, H.; van Dieren, M.C.A. Flowering and pollination studies with European plum (Prunus domestica L.) cultivars. Acta Hortic. 2010, 874, 193-202. [CrossRef]

2. Nikolić, D.; Milatović, D. Examining self-compatibility in plum (Prunus domestica L.) by fluorescence microscopy. Genetika 2010, 42, 387-396. [CrossRef]

3. Surányi, D. Comparative study of different fertile groups in plums. Int. J. Hortic. Sci. 2006, 12, 71-76. [CrossRef]

4. Sharafi, Y.; Ghanbari, A.; Naji, A.M.; Kordenaeej, A.; Rezaei, A. Comparison of pollen traits of some plum cultivars of Iran. Int. J. Agron. Plant Prod. 2013, 4, 314-318.

5. Nikolić, D.; Rakonjac, V.; Fotirić-Akšić, M. The effect of pollinizer on the fruitset of plum cultivar Čačanska Najbolja. J. Agric. Sci. 2012, 57, 9-18.

6. Nyéki, J.; Szabó, Z. Fruit set of plum cultivars under Hungarian ecological conditions. Acta Hortic. 1996, 423, 185-192. [CrossRef]

7. Kozma, P.; Nyeki, J.; Soltesz, M.; Szabo, Z. Floral Biology, Pollination and Fertilisation in Temperate Zone Fruit Species and Grape; Akadémiai Kiado: Budapest, Hungary, 2003; pp. 383-410.

8. Neumüller, M. Fundamental and applied aspects of plum (Prunus domestica L.) breeding. In Methods in Temperate Fruit Breeding. Fruit, Vegetable and Cereal Science and Biotechnology; Flachowsky, H., Hanke, V.M., Eds.; GSB: Kagawa, Japan, 2010; Volume 5, pp. 139-154.

9. Sutherland, B.G.; Cerović, R.; Robbins, T.P.; Tobutt, K.R. The myrobalan (Prunus cerasifera L.): A useful diploid model for studying the molecular genetics of self-incompatibility in plums. Euphytica 2009, 166, 385-398. [CrossRef]

10. Wertheim, S.J.; Schmidt, H. Flowering, pollination and fruit set. In Fundamentals of Temperate Zone Tree Fruit Production; Tromp, J., Webster, A.D., Wertheim, S.J., Eds.; Backhuys Publishers: Leiden, The Netherlands, 2005; pp. 1-400.

11. Meland, M. Efficacy of Chemical Bloom Thinning Agents to European Plums. Acta Agric. Scand. 2007, 57, 235-242. [CrossRef]

12. Meland, M.; Maas, F.M. Regulation of fruiting in plum production. In Proceedings of the 6th Conference Innovation in Fruit Growing, Belgrade, Serbia, 14-17 November 2017; Faculty of Agriculture: Peradeniya, Srilan, 2017; pp. 51-67.

13. Thompson, M.M.; Liu, L.J. Temperature, fruit set and embryo sac development in Italian prune. J. Am. Soc. Hortic. Sci. 1973, 98, 193-197.

14. Williams, R.R. Factors affecting pollination in fruit trees. In Physiology of Tree Crops; Luckwill, L.C., Cutting, C.V., Eds.; Academic Press: London, UK, 1970; pp. 193-207.

15. Tubiello, F.N.; Soussana, J.F.; Howden, S.M. Crop and pasture response to climate change. Proc. Natl. Acad. Sci. USA 2007, 104, 19686-19690. [CrossRef] [PubMed]

16. Beppu, K.; Suehara, T.; Kataoka, I. Embryo sac development and fruit set of Satohnishiki sweet cherry as affected by temperature, GA3 and paclobutrazol. J. Jpn. Soc. Hortic. Sci. 2001, 70, 157-162. [CrossRef] 
17. Sanzol, J.; Herrero, M. The effective pollination period in fruit trees. Sci. Hortic. 2001, 90, 1-17. [CrossRef]

18. Đorđević, M.; Cerovic, R.; Radičević, S.; Nikolić, D.; Milošević, N.; Glišić, I.; Marić, S.; Lukić, M. Pollen tube growth and embryo sac development in 'PoznaPlava' plum cultivar related to fruit set. Erwerbsobsbau 2019, 61, 313-322.

19. Horvath, A.; Balsemin, E.; Barbot, J.C.; Christmann, H.; Manzano, G.; Reynet, P.; Laigret, F.; Mariette, S. Phenotypic variability and genetic structure in plum (Prunus domestica L.), cherry plum (P. cerasifera Ehrh.) and sloe (P. spinosa L.). Sci. Hortic. 2011, 129, 283-293. [CrossRef]

20. Xuan, H.; Ding, Y.; Spann, D.; Möller, O.; Büchele, M.; Neumüller, M. Microsatellite markers (SSR) as a tool to assist in identification of European plum (Prunus domestica L.). Acta Hortic. 2011, 918, 689-692. [CrossRef]

21. Halapija Kazija, D.; Jelacic, T.; Vujevic, P.; Milinovic, B.; Cicek, D.; Bisko, A.; Pejic, I.; Simon, S.; Zulj Mihaljevic, M.; Pecina, M.; et al. Plum germplasm in Croatia and neighboring countries assessed by microsatellites and DUS descriptors. Tree Genet. Genom. 2014, 10, 761-778. [CrossRef]

22. Sehic, J.; Nybom, H.; Hjeltnes, S.H.; Gaši, F. Genetic diversity and structure of Nordic plum germplasm preserved ex situ and on-farm. Sci. Hortic. 2015, 160, 195-202. [CrossRef]

23. Merkouropoulos, G.; Ganopoulos, I.; Tsaftaris, A.; Papadopoulos, I.; Drogoudi, P. Combination of high resolution melting (HRM) analysis and SSR molecular markers speeds up plum genotyping: Case study genotyping the Greek plum GeneBank collection. Plant Genet. Resour. 2017, 15, 366-375. [CrossRef]

24. Makovics-Zsohár, N.; Tóth, M.; Surányi, D.; Kovács, S.; Hegedús, A.; Halász, J. Simple sequence repeat markers reveal hungarian plum (Prunus domestica L.) germplasm as a valuable gene resource. HortScience 2017, 52, 1655-1660. [CrossRef]

25. Urrestarazu, J.; Errea, P.; Miranda, C.; Santesteban, L.G.; Pina, A. Genetic diversity of Spanish Prunus domestica L. germplasm reveals a complex genetic structure underlying. PLoS ONE 2018, 13, e0195591. [CrossRef]

26. Pop, R.; Harta, M.; Szabo, K.; Zânescu, M.; Sisea, C.R.; Catana, C.; Pamfil, D. Genetic diversity and population structure of plum accessions from a Romanian germplasm collection assessed by simple sequence repeat (SSR) markers. Not. Bot. Horti Agrobot. Cluj Napoca 2018, 46, 90-96. [CrossRef]

27. Decroocq, V.; Hagen, L.S.; Favé, M.-G.; Eyquard, J.-P.; Pierronnet, A. Microsatellite markers in the hexaploid Prunus domestica species and parentage lineage of three European plum cultivars using nuclear and chloroplast simple-sequence repeats. Mol. Breed. 2004, 13, 135-142.

28. Gasi, F.; Pojskić, N.; Kurtovic, M.; Kaiser, C.; Hjeltnes, S.H.; Fotiric-Aksic, M.; Meland, M. Pollinizer efficacy of several 'Ingeborg' pear pollinizers in Hardanger, Norway, examined using microsatellite markers. HortScience 2017, 52, 1722-1727. [CrossRef]

29. Nishio, S.; Takada, N.; Terakami, S.; Kato, H.; Inoue, H.; Takeuchi, Y.; Saito, T. Estimation of effective pollen dispersal distance for cross-pollination in chestnut orchards by microsatellite-based paternity analyses. Sci. Hortic. 2019, 250, 89-93. [CrossRef]

30. Scorza, R.; Kriss, A.B.; Callahan, A.M.; Webb, K.; Demuth, M.; Gottwald., T. Spatial and temporal assessment of pollen- and seed- mediated gene flow from genetically engineered plum Prunus domestica. PLoS ONE 2013, 8, e75291. [CrossRef]

31. Dirlewanger, E.; Cosson, P.; Tavud, M.; Aranzana, M.J.; Poizat, C.; Zanetto, A.; Arús, P.; Laigret, F. Development of microsatellite markers in peach [Prunus persica (L.) Batsch] and their use in genetic diversity analysis in peach and sweet cherry (Prunus avium L.). Theor. Appl. Genet. 2002, 105, 127-138. [CrossRef]

32. Decroocq, V.; Favé, M.G.; Hagen, L.; Bordenave, L.; Decroocq, S. Development and transferability of apricot and grape EST microsatellite markers across taxa. Theor. Appl. Genet. 2003, 106, 912-922. [CrossRef]

33. Cipriani, G.; Lot, G.; Huang, W.G.; Marrazzo, M.T.; Peterlunger, E.; Testolin, R. AC/GT and AG/CT microsatellite repeats in peach [Prunus persica (L) Batsch]: Isolation, characterization and cross-species amplification in Prunus. Theor. Appl. Genet. 1999, 99, 65-72. [CrossRef]

34. Nei, M. Molecular Evolutionary Genetics; Columbia University Press: New York, NY, USA, 1978; pp. 1-512.

35. Hardy, O.J.; Vekemans, X. A versatile computer program to analyse spatial genetic structure at the individual or population level. Mol. Ecol. Notes 2002, 2, 618-620. [CrossRef]

36. Meirmans, P.G.; Van Tienderen, P.H. Genotype and Genodive: Two programs for the analysis of genetic diversity of asexual organisms. Mol. Ecol. Notes 2004, 4, 792-794. [CrossRef]

37. Hammer, Ø.; Harper, D.A.T.; Ryan, P.D. PAST: Paleontological statistics software package for education and data analysis. Palaeontol. Electron. 2001, 4, 9.

38. Ogašanović, D. The most suitable pollinators for new plum cultivars. J. Yugosl. Pomol. 1985, 19, $109-115$. 
39. Biddinger, D.J.; Joshi, N.K.; Rajotte, E.G.; Halbrendt, N.O.; Pulig, C.; Naithani, K.J.; Vaughan, M. An immuno marking method to determine the foraging patterns of Osmia cornifrons and resulting fruit set in a cherry orchard. Apidologie 2013, 44, 738-749. [CrossRef]

40. Hagler, J.R.; Mueller, S.; Teuber, L.R.; Machtley, S.A.; Van Deynze, A. Foraging range of honey bees, Apis mellifera, in alfalfa seed production fields. J. Insect Sci. 2011, 11, 144. [CrossRef] [PubMed]

41. Wolf, S.; Moritz, R.F.A. Foraging distance in Bombus terrestris L. (Hymenoptera: Apidae). Apidologie 2008, 39, 419-427. [CrossRef]

42. Zurbuchen, A.; Landert, L.; Klaiber, J.; Müller, A.; Hein, S.; Dorn, S. Maximum foraging ranges in solitary bees: Only a few individuals have the capability to cover long foraging distances. Biol. Conserv. 2009, 143, 669-676. [CrossRef]

43. Lankinen, Å.; Smith, H.G.; Andersson, S.; Madjidian, J.A. Selection on pollen and pistil traits during pollen competition is affected by both sexual confl ict and mixed mating in a self-compatible herb. Am. J. Bot. 2016, 103, 541-552. [CrossRef]

44. Rodrigo, J.; Herrero, M. Effects of pre-blossom temperatures on flower development and fruit set in apricot. Sci. Hortic. 2002, 92, 125-135. [CrossRef]

45. Meland, M.; Frøynes, O.; Coop, L.; Kaiser, C. Modeling of sweet cherry flowering based on temperature and phenology in a mesic Nordic climate. Acta Hortic. 2017, 1162, 19-22. [CrossRef]

46. Kemp, H.; Wertheim, S.J. Bestuiving. In 19e Rassenlijst Voor Groot Fruitgewassen; CPRO-DLO: Wageningen, The Netherlands, 1999; pp. 1-238. (In Dutch)

47. Keulemans, J. The effect of temperature on pollen tube growth and fruit set on plum trees. Acta Hortic. 1984, 149, 95-101. [CrossRef]

(C) 2020 by the authors. Licensee MDPI, Basel, Switzerland. This article is an open access article distributed under the terms and conditions of the Creative Commons Attribution (CC BY) license (http://creativecommons.org/licenses/by/4.0/). 